\title{
Commercial bank financing for micro-enterprises and SMEs in Mexico
}

\author{
Ramón Padilla-Pérez and Rodrigo Fenton Ontañon
}

ABSTRACT

This article examines commercial bank lending strategies for micro-enterprises and small and medium-sized businesses (SMES) in Mexico, and the factors that promote or hinder lending in this segment. With this in mind, in 2011 a detailed survey was conducted of commercial banks operating in Mexico. Although credit to microenterprises and SMES still represents a small share of the loan portfolio, the survey results point to growing interest in broadening it. Three different business models were identified, with major differences in strategies for offering financial services to this segment of enterprises. The greatest barriers to increasing the credit supply are lack of information, creditor protection failures, informality, and the changes and disruptions that commercial banking has experienced over the past three decades.

JEL CLASSIFICATION

KEYWORDS

AUTHORS
G21, L29, O16

Small firms, medium-sized firms, business financing, commercial loans, bank lending, businesses, surveys, Mexico

Ramón Padilla-Pérez is an Economic Affairs Officer with the International Trade and Industry Unit of the ECLAC subregional headquarters in Mexico. ramón.padilla@cepal.org

Rodrigo Fenton Ontañon is Vice President of Investment Banking with Bulltick Capital Markets and former Deputy Director General for Economic Affairs with the National Banking and Securities Commission (cNBv) of Mexico.rfenton@bulltick.com 


\section{I}

\section{Introduction}

The economic literature of the past few decades has abounded with discussion of the financial sector's role in economic growth. The great majority of authors agree that the sector plays a key part in growth because it provides services that are essential in today's economy: among other functions, it facilitates trade and production specialization, promotes saving and capital accumulation, makes resource use more efficient and diversifies risk.

As a facilitator of industrial growth, the financial system plays a central role in establishing and strengthening firms. Production schemes, especially long-term, largescale projects, need a system capable of capturing and allocating the resources of multiple savers (Bencivenga and Smith, 1991). Micro-enterprises and small firms usually have limited resources of their own and look to the financial system for the means to set up or grow their business.

The evidence available in the large body of literature on access to financing in Mexico supports consensus that the lending portfolio to the production sector is limited - especially in the case of micro-enterprises and small and medium-sized businesses (SMEs) (see, for example, Garrido and Prior, 2006; Lecuona, 2009). Although it has grown steadily in real terms since 2004, the total portfolio in this sector remains modest in relation to the size of the Mexican economy (banks' lending portfolio to private business represents around 7\% of GDP). $\square$ The authors are grateful to Pablo Peña, Saidé Salazar, Willy Zapata and Juan Carlos Moreno-Brid for their comments on preliminary versions of this article, and to Darío Luna, Raúl Hernández Coss, Luis Treviño, Sirenia Vázquez and Yearim Valles for their contributions in designing and planning the research. Support was also gratefully received at different stages of the project from Althea Spinozzi, Jesús Dávila, Jesús Santamaría and Verónica Vega. Lastly, the authors express their thanks to the Association of Banks of Mexico and the banks which took part in the study.

$\square$ The opinions expressed in this document are those of the authors and may not coincide with those of the organizations in which they work.
This article analyses a particular aspect of the Mexican financial system's contribution to economic development — commercial banks' small business lending strategies - and examines the factors that stimulate or obstruct this lending. To this end, it summarizes the results of a technical collaboration project conducted by the National Banking and Securities Commission (CNBV) of Mexico and the Economic Commission for Latin America and the Caribbean (ECLAC). ${ }^{1}$ The analysis is based on the results of a questionnaire designed by CNBV and ECLAC to examine the business strategy adopted by commercial banks in their dealings with micro-enterprises and SMEs and to obtain information that would refute or validate the importance of a series of previously identified factors.

A vast body of literature exists on Mexico's financial system, ${ }^{2}$ addressing a broad range of subjects from its historical development to the functioning of specific aspects such as the system of guarantees. Yet none was found on the factors facilitating or hindering credit to firms on the basis of a survey of commercial banks.

This article has six sections including this introduction. Section II reviews the theoretical and empirical literature on the relationship between financial system development and economic growth, and identifies eight factors that could potentially be related to the supply of credit to the production sector. Section III sets forth the methodology used to collect empirical evidence. Section IV analyses the first part of the questionnaire results (the business model), and section $\mathrm{V}$ examines the importance of obstacles to credit in Mexico. Section VI concludes and suggest future lines of research.

1 The full report on the project is available in Fenton and PadillaPérez (2012).

2 See, for example, Tovilla (2002); Garrido (2005); Ávalos and Hernández (2006); Castañeda and Ruiz (2006); Lecuona (2009); Suárez Dávila (2010), and Pavón (2010). 


\section{II}

\section{Financing for production development: importance and potential obstacles}

The economic literature on the relationship between financial system development and economic growth is abundant and wide-ranging. The theoretical literature and the empirical evidence largely agree that the two are positively correlated, because the financial system plays a crucial role in reducing transaction and information costs, and facilitates efficient resource allocation. Nevertheless, some authors argue that the financial system's importance for economic growth has been overstated (Lucas, 1988; Chandavarkar, 1992).

The financial system has five main functions as an engine of industrial development. ${ }^{3}$ The first is to reduce risk through coverage, commerce and diversification (Bencivenga and Smith, 1991). This function is essential for technological innovation, which is typically a long, slow process (Audretsch, Werner and Mahagaonkar, 2009).

The second function is to compile information and allocate resources. By reducing information asymmetries between lenders and borrowers, the financial system channels resources to the most productive sectors, encouraging economic efficiency and social well-being (Greenwood and Jovanovic, 1990; Habibullah and Eng, 2006).

The third function is to mobilize individual and grouped savers looking to invest their resources. The financial system brings together the resources of numerous savers for allocation to large and productive projects (Sirri and Tufano, 1995).

The fourth function is to reduce the costs of compiling the information needed to enforce contracts and oversee the behaviour of borrower firms. This function promotes capital accumulation and efficient resource allocation and, consequently, long-term growth (Levine, 1997; Rajan and Zingales, 1998).

The fifth and final function is to facilitate specialization by reducing transaction costs. Specialization allows firms to concentrate on production activity, by giving them the space to improve their processes and products and thus increase their productivity (Stiglitz, 1989; Greenwood and Smith, 1997; Cooley and Smith, 1998).

\footnotetext{
3 This systematization is based on the work of Levine (1997)
}

A broad literature exists on how the degree of development of a country's financial system affects its economic growth and the relationship between the two has been analysed minutely using various econometric techniques. Most empirical studies offer evidence that the two variables are positively correlated. ${ }^{4}$

The factors encouraging or hindering financing for small businesses may be grouped by supply side and demand side. On the supply side are formal and informal mechanisms of financing for firms and, on the demand side, the individuals and companies seeking financial resources to begin, operate or strengthen their production activities.

This study concentrates on factors that could limit the supply of commercial bank credit to microenterprises and SMEs. A comprehensive review of the literature identified eight such factors (see table 1). Several studies show that a multidimensional analysis is needed, because there is no single cause to explain the supply or absence of credit to the business sector. The list is to be construed as a set of hypotheses that are to be refuted or validated by the results of a questionnaire of commercial banks in Mexico, as explained in greater detail in the following section. The eight factors are described below.

TABLE 1

Mexico: factors potentially linked to credit supply to SMEs and micro-enterprises

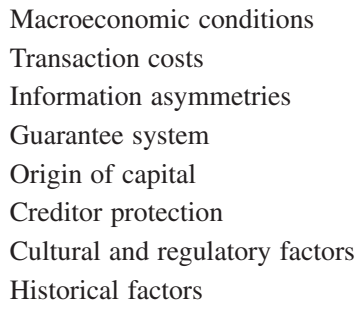

Source: prepared by the authors.

4 See, for example, Arestis, Demetriades and Luintel (2001); Benhabib and Spiegel (2000); Leitao (2010); Rajan and Zingales (1998); Saci, Giorgioni and Holden (2009); Bittencourt (2010); Blanco (2010); Habibullah and Eng (2006); Caporale and others (2009). 
Business cycles heavily influence the availability of funds for credit (Garrido, 2005). The supply of financing tends to dwindle under very tight monetary policy, because banks themselves have less financing and financial resources are in shorter supply in the market in general (Barajas and Steiner, 2002). Monetary policy not only affects short-term interest rates, but also brings about changes in bank reserves and deposits and thereby the availability and cost of credit. Banks tend to reduce their credit supply in times of macroeconomic instability because risk is greater. In countries that suffer lengthy periods of instability or that are very vulnerable to economic shocks, credit to the business sector tends to be more limited and interest rates tend to be higher.

From the creditor's point of view, lending carries a variety of costs associated with evaluation, oversight and collections. Transaction costs may be divided into overheads, which exist regardless of the value of the transaction, and costs arising from lack of adequate information. For SMEs and micro-enterprises, overheads tend to be high in relation to the amount lent because firms in this segment usually apply for quite small loans. The cost rises further if there are no credit rating instruments to provide rapid, reliable information on the firm. Banks may therefore change high rates of interest to secure an attractive return from this segment, which makes financing more difficult for small businesses (Garmendia, 2006).

Lack-of-information costs have to do with the excessive administrative work involved in finding adequate documentation, and they affect a bank's decision on whether to assess the loan application at all. If the requesting firm has not compiled all the documents needed to obtain financing, the loan application review process drags on and increases the bank's costs in terms of the human resources monitoring and evaluating the project (Lecuona, 2009).

Information asymmetries arise when the borrower has more information than the lender. When the value and quality of a firm or project cannot be accurately calculated, banks have no guarantee of their future success. This problem is especially acute in the case of small businesses and reflects the general lack of information about them. Without solid data, the bank cannot evaluate a firm objectively, making it very difficult to establish the firm's future ability to generate returns (Audretsch, Werner and Mahagaonkar, 2009). The main information asymmetries facing private banks in lending to microenterprises and SMEs are: (i) the high cost of obtaining credit information, (ii) inconsistent financial information, and (iii) lack of access to third-party information
(Malhotra and others, 2006). These asymmetries can lead to adverse selection or moral hazard (Stiglitz and Weiss, 1981; Lecuona, 2009).

Information asymmetry can lead to excess demand for credit, even where credit supply and demand are in equilibrium. This is known as "credit rationing" (Stiglitz and Weiss, 1981).

From the credit supply perspective, a number of obstacles can arise in relation to the system of guarantees. If a firm has no collateral to offer, the financial institution has less incentive to extend credit. It also has less incentive where the value of the collateral cannot be established. In addition, an ineffective public sector, weak institutions and failings in the legal system can make it very hard for financial institutions to realize guarantees in the case of default (World Bank, 2007).

Guarantees reduce borrowers' incentives to default, increase their motivation to succeed at a project and lower the costs of bankruptcy for the lender. Guarantees also address information asymmetry and uncertainty issues, and reduce the risk for the lender (Garmendia, 2006). However, micro-enterprises and SMEs often lack guarantees for loan application.

The literature on the implications of the origin of capital and the involvement of foreign banks in lending to SMEs is inconclusive, with studies coming down both in favour and against. Some authors assert that the entry of foreign banks can increase the supply of credit to SMEs and micro-enterprises because they tend to have comparative advantages in small business financing in terms of technologies and organizational structure (Berger and Udell, 2006).

Other authors argue that foreign banks are prejudicial to SMEs and micro-enterprises, because they tend to have a hierarchical organizational structure and treat collateral (which SMEs and micro-enterprises usually lack) as one of the most important factors in the lending decision. They also tend to be at a disadvantage vis-à-vis local banks when it comes to obtaining information (Beck, Demirgüç-Kunt and Martínez, 2010).

The existence of a guarantee system does not, in itself, expedite lending to the SME and micro-enterprise segment if there is no legal framework to enable creditors to recover the guarantees agreed should be borrower default. This is the case in countries with legal systems which tend to protect the borrower and where legal processes are lengthy and inefficient (Beck and de la Torre, 2007).

Haber (2005) mentions that in developing economies, even where the banking system has been freed up and banks behave in a prudent manner, in a context of weak 
contractual rights often they will simply not lend to small businesses.

Cultural factors can affect lending if borrowers lack good payment behaviour or if firms are highly informal, which increases risk for the lender. The culture of informality in firms also affects credit supply, because banks and financial institutions are not willing to lend to firms lacking the proper documentation (tax receipts, audited financial statements, and so forth). In an informal culture, firms may leave assets undeclared to avoid taxes, and therefore cannot use them as collateral for banking purposes (World Bank, 2007).

Regulatory factors can also hinder the supply of credit to micro-enterprises and SMEs, if they create conditions or procedures that obstruct bank lending or make it less profitable. Financial repression can also affect the credit supply. McKinnon (1973) found that

\section{III}

\section{Methodology}

This research project was undertaken in an effort to gain a fuller understanding of the strategies used by the commercial banking system in Mexico in its lending operations with micro-enterprises and SMEs. A number of surveys and studies on firms' access to bank credit in the country have been conducted, but they vary in terms of their coverage and the level of detail of the data compiled. ${ }^{5}$ These studies have all, however, used a demand-side approach, in that their authors have canvassed different firms in order to determine whether or not they have bank loans.

This study departs from that approach in that it takes a look at the supply side of the picture by asking banks about their corporate lending practices. To the authors' knowledge, this is the first study in which credit supply is analysed on the basis of a representative survey of commercial banks in Mexico. ${ }^{6}$ In determining what type

5 Examples include: the National Microbusiness Survey; the National Survey on Corporate Competitiveness, Funding Sources and Use of Financial Services; the evaluation of the credit-market cycle conducted by the Banco de México; and the Enterprise Surveys of the World Bank.

6 Studies on the supply of credit available to small and mediumsized enterprises (SMEs) in Mexico, such as the study prepared by the Latin American Banking Association (FELABAN, 2007), have been conducted on the basis of a survey of Latin American banks, but they have not been as detailed, and their national samples have not been many countries have historically restricted financial sector operations through government intervention or regulation.

Long-term relations between bankers and businesses are important for lending, because they complement the numerical information - which banks use to evaluate firms - with qualitative information, including prestige and reputation, and help to reduce information asymmetry problems. Relations between bankers and businesses facilitate lending even in times of credit squeeze, as in financial crises (De la Torre, Martínez Pería and Schmukler, 2008).

A last factor that affects credit supply is political and economic stability. Generally speaking, banks lend more to business in countries that are politically very stable, where there is no risk of nationalization and their assets are more secure. of information would be useful and how to go about gathering it, the fact that there would be a relatively small number of observations (banks) was taken into account.

The National Banking and Securities Commission (CNBV) and the Mexican Banking Association (ABM) jointly identified the banks that lend to micro-enterprises and sMEs on the basis of regulatory reports and the two organizations' in-depth knowledge of the market. This target universe was made up of 17 out of the 40 banks operating in the country. According to ABM and CNBV, these 17 banks are the only ones that extend credit to micro-enterprises and SMEs. Those that do not engage in such lending operations were not included in the target universe.

ECLAC and CNBV designed and used two tools for gathering information on commercial banks that lend to micro-enterprises and SMEs: a questionnaire and an in-depth interview. In the end, information was obtained from 15 of the 17 banks that were contacted. Those 15 banks account for $97 \%$ of the commercial banking system's portfolio of loans to micro-enterprises and SMEs in Mexico.

representative. There are also studies based on secondary data, such as that of Lecuona (2009). 
The questionnaire contained 77 queries (a mixture of numeric and open-ended questions) designed to elicit information on bank managers' views on various matters. ${ }^{7}$ The queries were grouped into three sections. One focused on the strategy used in dealing with microenterprises and SMEs, another on the banks' business models for this clientele, and the third on operational aspects of their loans to micro-enterprises and SMEs. ${ }^{8}$

7 The questionnaire may be found in the complete report, which is cited in the first footnote of this article.

8 A preliminary version of the questionnaire was shown to ABM, and the feedback that it provided was used to adjust some of the questions in the interests of clarity.
ABM helped the interviewers to contact the most suitable executives in each bank, who were, for the most part, the managers in charge of the section of the bank responsible for business with micro-enterprises and SMEs or, in banks where no such section exists, the executives who deal with that segment of the market. Once the questionnaire had been sent, respondents took an average of four weeks to return it.

The in-depth interviews were conducted after the completed questionnaires had been received. Between June and August 2011, the authors visited the banks in order to delve more deeply into the responses given to the open-ended questions. These interviews lasted between 90 and 120 minutes.

\section{IV}

\section{Business model}

One basic fact that must be borne in mind when seeking to gain an understanding of the business models used by commercial banks in Mexico is that they are highly heterogeneous. These banks differ from one another not only in terms of clearly observable attributes (the scale of their operations or their sources of capital) but also in terms of comparative advantages and their overall business approaches. These differences determine whether or not they lend to micro-enterprises and SMEs and, if so, what approach they will take to that segment of the market.

As noted earlier, there are more than 40 different banks in Mexico, but fewer than half of them (17) lend to micro-enterprises and SMEs, according to the information provided by ABM and CNBV. ${ }^{9}$ Several foreign banks extend credit to this segment of the market in other countries but not in their Mexican branches. In conversations with executives from these banks, no one mentioned any specific restriction in that regard. Instead, the executives simply mentioned that their business activities in Mexico did not, for the time being, include that type of loan product, partly because they were concentrating on more profitable lines of business, such as investment banking.

Of the 15 banks that responded, 11 have a specialized business unit to handle operations with micro-enterprises

9 This universe does not include all banks that offer microcredits, which constitute a segment that has differing characteristics and strategies. and SMEs and a specific strategy for its dealings with them. These units are generally in charge of setting targets and benchmarks, identifying banking products, prospecting potential clients, and granting and monitoring loans in this segment. These banks usually also have a specialized sales force.

Commercial banks do not all define micro-enterprises and SMEs in the same way, since this depends on the operational criteria and business strategy used by each institution. Some use a firm's sales volume, while others base their definition on the amount of credit involved. For the purposes of this study, an attempt has been made to consolidate the classifications used by the banks in the sample.

At the time of the interviews, the banks reported that their total portfolio of micro-enterprise and SME loans amounted to 119 billion pesos distributed among 200,000 different loans. Their micro-enterprise and SME portfolios represented $19.4 \%$, on average, of their total commercial loan portfolio, but for the individual banks, this percentage ranged from $2.5 \%$ to $75.6 \%$.

In most cases, the bank executives emphasized that the first step in competing for new clients was to offer deposit-taking products such as current or savings accounts or salary payment accounts. The representatives of banks that do not have a special unit for micro-enterprise and SME loans were the only ones who openly admitted that the intention was not to provide the full range of services to those clients. None of the interviewees said 
that credit was their main or only product. In fact, 11 of these 15 banks offer more than five different products to their clients in the micro-enterprise and SME segment, such as current accounts, lines of credit, salary payment accounts and special business credit cards. Lines of credit and lines of working capital are the most common loan products.

On the basis of the survey results, the approaches taken by these banks in offering credit to the microenterprise and SME segment can be classified as corresponding to one of three business models. It should be emphasized, however, that these models do not necessarily represent a rigid, fixed classification of all their different lines of business.

(i) Large banks. Their strategy consists of serving as many clients as they can attract through their network of branch offices or specialized promotional personnel. They are able to benefit from economies of scale and are the biggest small-business lenders.

(ii) Banks with close ties to micro-enterprises and SMEs. These are niche banks devoted to promoting entrepreneurship and the production sector of the economy or regional banks that specialize in certain market segments. They use relationship lending to attract clients. (iii) Banks that do not have specialized micro-enterprise/ SME units. This category includes banks that offer loans to this segment only as an extension of their traditional lines of business in order to provide their existing clients with an additional service.

Figure 1 shows the range of clients served by the banks in these three categories. The large banks' clients include smaller firms, with some of them even beginning to deal with companies that have annual sales of less than 100,000 pesos. Banks that maintain ties with micro-enterprises and SMEs serve larger firms, while those without specialized units for this segment work only with firms having annual sales of over 4,000,000 pesos. This leads to the conclusion that the commercial banking system primarily lends to small and mediumsized firms in this segment, while it provides financing to no more than a small group of micro-enterprises.

Annual interest rates on loans to micro-enterprises and SMEs vary according to the size of the firm, the sector in which it operates and the type of business concerned. On average, the rates reported in the interviews are as follows:

Microenterprises: $\quad 16.3 \%-26.8 \%$.

Small enterprises: $\quad 11.1 \%-17.3 \%$.

Medium-sized enterprises: $\quad 8.8 \%-13.2 \%$.

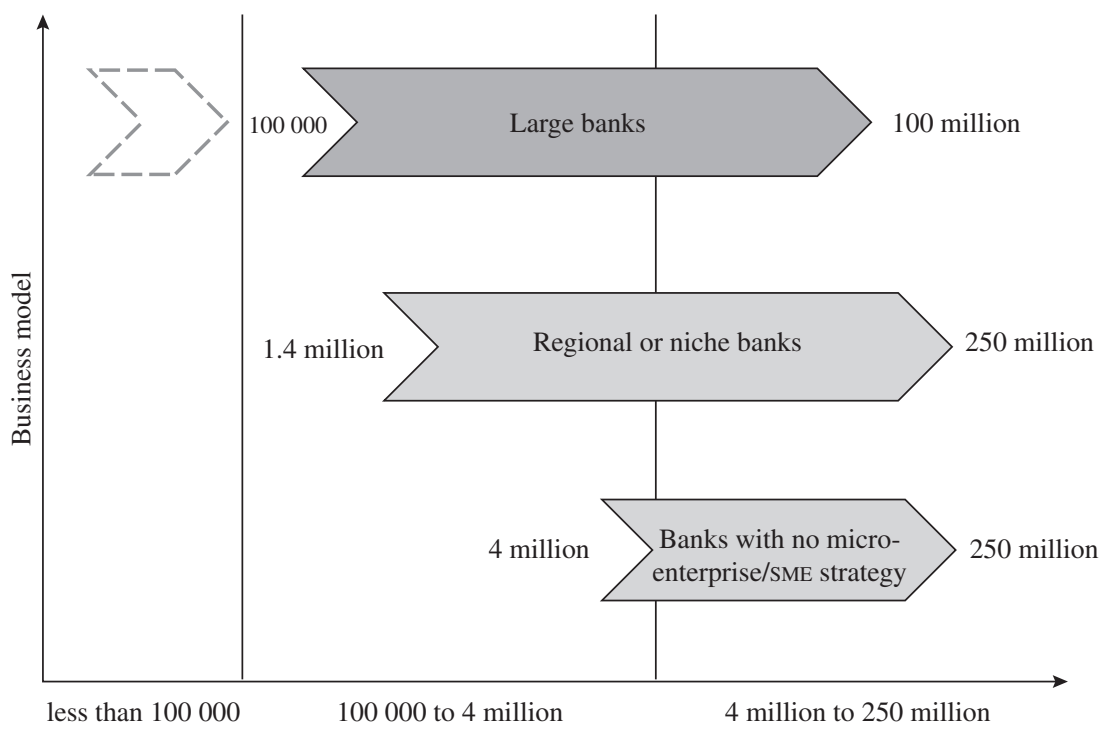

Source: prepared by the authors. 


\section{V}

\section{Analysis of obstacles}

This section aims to validate or refute the significance of each of the previously identified factors that are potentially linked to credit supply in Mexico, on the basis of the information obtained from the bank survey conducted for this study.

\section{Macroeconomic conditions}

The questionnaire included queries to identify how banks incorporate macroeconomic conditions into their decisions on lending to micro-enterprises and SMEs and to establish whether these conditions have encouraged or hindered lending. Seventy-one per cent of the banks surveyed (accounting for $82.9 \%$ of the micro-enterprise and SME lending portfolio) considered the performance of macroeconomic variables in setting targets and in the extension of loans to this business segment. Macroeconomic variables were generally used to set lending and deposit-taking targets, and to assess risk and allocate portfolios by sector and region.

The different variables are commonly used to estimate the macroeconomic risk associated with the portfolio of loans to micro-enterprises and SMEs and to establish total portfolio and lending amounts. For large firms, assessment and inclusion of macroeconomic variables in credit assessment is done on an individual, case-bycase basis. The executives of the banks canvassed also said that small businesses tend to be more vulnerable to macroeconomic shocks, and that this is taken into account in lending decisions.

When requested to describe an occasion on which macroeconomic variables had prevented lending, 53\% of the banks interviewed ( $78.2 \%$ of the portfolio) cited the economic crisis of 2008-2009 and the public health emergency arising from the H1N1 influenza outbreak.

Sixty-nine per cent of the banks interviewed ( $90.3 \%$ of the portfolio) stated that poor macroeconomic performance dampened incentives to lend to microenterprises and SMEs. High volatility, uncertainty and slowing economic activity do affect the credit supply, and did so during recent economic crisis (1995 and 2008-2009). At the time of the interviews, however, (June-August 2011), economic conditions were brighter and were not constraining credit supply. Macroeconomic factors affect lending to micro-enterprises and SMEs and to large firms, but in the former case credit is more vulnerable to adverse economic conditions.

\section{Transaction costs}

Fifty-three per cent of the banks interviewed (73\% of the portfolio) were able to estimate transaction costs as a proportion of the loans extended to microenterprises and SMEs. The remaining banks argued that this information was not available, because it was not a routinely performed calculation. Transaction costs are defined as the expenses the bank incurs to bring about a loan contract, not including funding costs ${ }^{10}$ or default losses. The main components of transaction costs are: marketing and loan origination; loan underwriting, approval and extension; loan performance supervision and collection; and litigation for recovery of arrears.

On average, the transaction cost was $2.8 \%$ of the sum lent (2.9\% in weighted average for the portfolio). However, that cost varied significantly (from $1 \%$ to $7 \%$ ) among the banks interviewed. The largest component was marketing and loan origination, which - on averagemake up $50 \%$ of the total transaction costs $(51 \%$ in the weighted average), followed by loan underwriting, approval and extension (30\% in the simple average and $27 \%$ in the weighted average), and loan performance supervision and collection (10\% in the simple average and $12 \%$ in the weighted average) (see table 2). Only three banks gave an estimate of transaction costs for large firms as well. In all three cases, the costs were lower than for small businesses.

The minimum level below which is it not profitable to lend to micro-enterprises and SMEs varied among the banks interviewed, depending on their business model and size. The average cut-off point was 420,000 pesos (310,000 pesos in the weighted average for the portfolio), but ranging from 18,000 to 3 million pesos. Banks with smaller portfolios and fewer loans to micro-enterprises and SMEs tended to stipulate higher minimum loans than banks with large, numerous portfolios. $75 \%$ of the banks interviewed ( $76.5 \%$ of the portfolio) considered lending

\footnotetext{
10 The funding cost is the financial cost the bank pays to its own
} creditors for the resources it lends. 
to a micro-enterprise or SME more risky than lending to a large firm, but $58 \%$ (46.5\% of the portfolio) estimated that it was also more profitable.

Executives in $57 \%$ of the banks $(24.8 \%$ of the portfolio) stated that higher transaction costs represented a barrier to lending to small businesses. Among the banks interviewed there was a general opinion that lending to micro-enterprises and SMEs is a business of scale, inasmuch as a bank needs to have a large network of branches and executives trained to cater to this segment to reach worthwhile figures. Accordingly, transaction costs are not a barrier for banks with large and numerous micro-enterprise and SME portfolios, but they can be for banks with smaller portfolios.

TABLE 2

Mexico: composition of transaction costs in lending to micro-enterprises and SMEs, average for the firms interviewed

(Percentages)

\begin{tabular}{|c|c|c|}
\hline & Simple average & Weighted average \\
\hline Marketing and loan origination & 50 & 51 \\
\hline Loan underwriting, approval and extension & 30 & 27 \\
\hline Loan performance supervision and credit collection & 10 & 12 \\
\hline Collection of credit arrears & 7 & 7 \\
\hline Litigation for collection of defaulted loans & 3 & 2 \\
\hline
\end{tabular}

Source: prepared by the authors.

\section{Information asymmetries}

Three steps are generally taken to counter information asymmetries:

(i) All the banks interviewed offer other products to micro-enterprises and SMEs, as well as lines of credit. As noted earlier, $73 \%$ offer more than five different products. As well as leveraging the relationship with the firm, this strategy enables the bank to build up information about the firm's business performance and owners, or both, by tracking its checking, credit card and payroll transactions, for example.

(ii) All the banks interviewed ask micro-enterprises and SMEs to give evidence of having been in operation for at least two years in order to qualify for credit. This is premised on the general idea that $80 \%$ of small businesses disappear within the first two years. A firm over two years old is therefore deemed to be more likely to survive and, therefore, to be able to repay a loan. ${ }^{11}$

(iii) None of the banks interviewed lend to start-ups, because it is very difficult to assess the project's chances of success. Exceptionally, loans may be extended to businesspeople trying to start up a new business, with a jointly liable signatory who has

\footnotetext{
11 Refers to payments made by the borrower to the bank to reimburse the capital lent.
}

good relations with the bank. ${ }^{12}$ Four large banks participate in a scheme run by the Ministry of the Economy to extend financing to entrpreneurs, ${ }^{13}$ but at the time of the interviews very few loans had actually been extended. ${ }^{14}$

Ninety-three per cent of the banks interviewed (98.9\% of the portfolio) consult a credit bureau ${ }^{15}$ to obtain background information on micro-enterprises and SMEs, their owners, or both. Almost three quarters $(73 \%)$ of the banks interviewed ( $82 \%$ of the portfolio) said that the information from private credit and debtor information registries was reliable or very reliable (a rating of 4 or 5 , on a scale of 1 to 5 ). $54 \%$ of the banks interviewed ( $58.1 \%$ of the portfolio) considered that the credit bureaux databases provided enough information on a micro-enterprise or SME to determine its risk profile, whereas the other banks considered this information insufficient and complemented it with another source of data.

\footnotetext{
12 A guarantor from whom the bank is entitled to demand resources on the same terms and conditions as from the borrower, or who can be legally obliged to cover payment of capital and interest.

13 The Entrepreneur Financing Programme aims to encourage and promote commercial bank lending to entrepreneurs with technically, commercially and financially viable schemes. See www.economia. gob.mx for more information about this programme.

14 See Tovilla (2002) and Pino (2002).

15 Credit bureaus are defined in Mexican law as "credit information agencies" or Sociedad de Información Crediticia (SIC).
} 
Eighty-seven per cent of the banks interviewed (94\% of the portfolio) use credit score models for microenterprises and SMEs. The weight of the model's results in the lending decision varies from one bank to another and depends, among other things, on the amount of the loan and the size of the firm. Generally speaking, the larger the loan, the more other criteria are needed in addition to the credit score model.

In $64 \%$ of the interviews ( $87.1 \%$ of the portfolio) the bank stated that insufficient or poor quality information was a barrier to lending to micro-enterprises and SMEs. Information asymmetry is an obstacle for a small business with less than two years in operation, and for entrepreneurs. For older firms, there are sources of information and evaluation mechanisms that counter asymmetries. Private registries of information on credit and borrowers are considered a reliable source for assessing a firm and its owner.

\section{Guarantee system}

Sixty-four per cent of the banks interviewed (66\% of the portfolio) stated that the collateral offered by a micro-enterprise or SME was very important (4 or 5, on a scale of 1 to 5) in securing loan approval. Some banks do not ask for collateral for certain types of firm or below certain amounts of loan, but they do assess the business in detail. The percentage of the portfolio of small businesses which have put up collateral varies greatly depending on the size of the bank, its business strategy and the length of time for which it has been lending to this segment.

In the midsize and small banks interviewed, 70\% of the commercial small business portfolio was backed by a pledge on physical assets, but the amount varied from $25 \%$ to $100 \%$. In large banks, these pledges are less significant (between $0 \%$ and $5 \%$ of the commercial portfolio, with an average of $1 \%$ ).

By contrast, the percentage of the portfolio with government guarantees in large banks averages $74 \%$, varying from $60 \%$ to $98 \%$. Some of these banks even stated that, in recent years, all new loans to micro-enterprises and SMEs have been backed by government guarantees, mainly provided by Nacional Financiera, S.N.C. (NAFIN). ${ }^{16}$ Among the smaller banks, the percentage of the portfolio secured by government guarantees is generally lower, averaging $40 \%$. Among the banks interviewed, $67.2 \%$ of the portfolio total is backed by government guarantees.

16 NAFIN is a Mexican development bank focused on promoting credit to the private sector.
For some of the banks interviewed, NAFIN guarantees do not replace physical collateral, which they require in addition to the government guarantee.

In $40 \%$ of the interviews ( $45.2 \%$ of the portfolio), banks stated that collateral requirements are greater for micro-enterprises and SMEs than for large firms, because they are usually less stable, more informal and harder to assess.

Eighty per cent of the banks interviewed (75.4\% of the portfolio) considered federal government guarantees more appropriate for micro-enterprises and SMEs than for large firms, because of the loan ceilings and because many SMEs would be unable to secure a loan at all without them.

In $90 \%$ of the banks interviewed $(88.2 \%$ of the portfolio) federal government guarantees were preferred to other collateral; the rest considered the two equally useful. The general preference reflects the fact that small businesses often have collateral of poor quality at their disposal. In addition, the government guarantees function as liquid collateral, whereas a pledge on physical assets can require lengthy legal processes, and recovering government guarantees is thus quicker and more expedite. The government guarantees also show a positive impact on reserves.

In the case of default, $60 \%$ of the banks interviewed (50.5\% of the portfolio) said that it was difficult or very difficult (rating of 1 or 2, on a scale of 1 to 5 , where 5 is very easy and 1 is very difficult) to seize physical collateral in case of default. Banks argued that the process was slow and costly and collateral guarantees hard to dispose of.

Fifty-seven per cent of the banks interviewed (57.3\% of the portfolio) stated that the collateral and government guarantee systems were sufficient to cover the risks of the small business portfolio. Opinions were more favourable among the large banks, which make more use of government guarantees. Banks which have less access to government guarantees generally stated less satisfaction with the guarantee system overall.

In addition to the questionnaire, other studies on credit guarantees in Mexico have found serious rule-of-law issues, which make it difficult to recover the guarantees written into loan contracts. It may be concluded that these issues directly affect banking activity and hinder credit expansion.

\section{Origin of capital}

Foreign-owned banks are responsible for most of the small business lending in Mexico owing to their predominance in commercial banking in general. Two thirds of the 
foreign-owned banks interviewed said their business model for micro-enterprises and SMEs in Mexico was different to the one they used in other countries. This is because they have different programmes and instruments and use other channels to reach clients (for example, more electronic media).

Ninety-two per cent of the banks interviewed ( $87.3 \%$ of the portfolio) stated that the nationality of the capital does not affect their willingness to lend to micro-enterprises and SMEs. The origin of capital is not a barrier to credit supply, insofar as the strategies used by Mexican and foreign banks do not differ.

At least three elements must be considered in comparing Mexican- and foreign-owned banks to establish whether the origin of capital plays a role in small business lending strategies. First, whether multinational banks behave differently in different countries, including in their home market. Second, any comparison must take into consideration other observable characteristics that lead to different business models, such as bank size. By and large, the foreign-owned banks are the largest ones. Third, the behaviour of Mexican-owned banks varies in a manner comparable to that of foreign-owned banks. Accordingly, distinguishing the origin of the capital may not be as informative as other characteristics.

\section{Creditor protection}

The banks gave very varied responses to questions on creditor protection. The simple average figure for loans to micro-enterprises and SMEs entering default (the arrears portfolio) is $6 \%$, but this ranges widely between banks, from $1.4 \%$ to $20 \%$. The average weighted by size of defaulting loan portfolio is $4.7 \%$. As noted earlier, the rate of successfully recovered guarantees attached to these loans is $76 \%$ on average, with differences ranging from $30 \%$ to $99 \%$ and a weighted average of $82 \%$. The banks with the highest ratios of successfully recovered guarantees are those which make most use of government guarantees.

The average amount recovered from a defaulted loan to a micro-enterprise or SME is $49 \%$ of the unpaid balance, but ranges from $2 \%$ to $100 \%$ among the banks interviewed. Weighted by size of portfolio recovered, the average is $51.4 \%$.

It takes 21 months, on average, to recover a defaulted loan to a micro-enterprise or SME (18.3 months when weighted by portfolio size), varying from 1 to 60 months among the banks interviewed. The simple average cost of recovery is $17 \%$ of the defaulted loan $(10.2 \%$ weighted by portfolio size), varying from $0.5 \%$ to $60 \%$.
Only $16 \%$ of the banks interviewed (13\% of the portfolio) considered the laws or regulations applicable to recovery of loans from a micro-enterprise or SME useful or very useful (4 or 5, on a scale of 1 to 5). The weaknesses of the legal system included: the length of time it takes to enforce a guarantee; distant dates for seizure proceedings; difficulty in delivering notifications; obstacles to conducting seizures; and complex, slow and costly legal actions.

Seventy-one per cent of the banks interviewed $(92.4 \%$ of the portfolio) maintained that a weak legal system for recovering defaulted loans represented a barrier to the supply of credit to micro-enterprises and SMEs. In sum, processes were slow and complicated, recovery times were long, and the legal route was very costly. These factors are not exclusive to the small business segment, however, but affect lending to large firms as well.

\section{Cultural and regulatory factors}

Informality affects the supply of credit to micro-enterprises and SMEs. Executives in $94 \%$ of the banks interviewed (74\% of the portfolio) said that informality strongly influenced the lending decision (a rating of 4 or 5 , on a scale of 1 to 5). Informality refers to firms that are not legally constituted or registered with the Ministry of Finance and Public Credit, have weak or unsystematic accounting practices or lack updated tax reports and financial statements.

Only $36 \%$ of the banks interviewed $(57.1 \%$ of the portfolio) thought it important or very important (a rating of 4 or 5 , on a scale of 1 to 5) to do away with the requirement for tax reports to boost small business lending. The percentage is low because several banks still ask for tax reports as evidence that a firm is legally established, even though this is not an official requirement.

Other cultural and regulatory factors which banks mentioned as affecting the credit include:

(i) The new methodology proposed by the authorities for parametric estimation of reserves to business loans contains variables that would increase the cost of lending to micro-enterprises and SMEs.

(ii) The highly complex tax legislation.

(iii) Insecurity, especially in the north of Mexico, limits some banks' credit supply or forced them to change their business assessment criteria.

(iv) The "won't pay" culture which characterizes many businesses and businesspersons.

(v) Lack of financial culture and professionalization on the part of micro-enterprises and SMEs. 
Ninety-three per cent of the banks interviewed (96.8\% of the portfolio) replied that cultural and regulatory factors, such as fiscal informality, lack of financial culture, or the "won't pay" culture prevailing in smaller firms formed obstacles to lending.

\section{Historical factors}

There is a high turnover among the staff and branches dealing with micro-enterprises and SMEs, with an average of 3.5 years on the job. Senior and middle managers tend to have been in place longer.

Departments for lending to micro-enterprises and SMEs, where they exist, are relatively new, even where this line of business is older the department itself. This is because of the changes in this area of business during the various deep transformations in Mexico's banking industry. Some banks have closed down and reopened their small business lending department in the past decade. Economic crises or problems with the business model have often led to lending being suspended and the strategy rethought.

Although 59\% of the banks interviewed $(82.3 \%$ of the portfolio) stated that staff stability in the lending

\section{VI}

\section{Conclusions}

The research described herein offers detailed information on commercial bank strategies for lending to microenterprises and SMEs, on the basis of an in-depth, representative survey of commercial banks in Mexico. This empirical work, the first of its type in Mexico, serves to validate or refute the hypotheses regarding barriers to lending in this segment. This analysis represents the supply-side view (commercial banks) and should be complemented with the demand-side perspective (firms).

In this regard, $\mathrm{CNBV}$ and the Inter-American Development Bank (IDB) recently conducted a survey of firms to ascertain in more detail how financial services, including bank credit, are used. The results of this demand-side study coincide in some respects with the supply-side research. For example, the firms canvassed said that credit lines were the most used product and that informality largely limited access to bank credit. Conversely, firms perceive that the greatest obstacle to securing bank credit is lack of sufficient guarantees (CNBV/IDB, 2012). segment was important or very important ( 4 or 5 , on a scale of 1 to 5), thereby confirming the importance of relationship lending, the continual and deep-reaching changes in Mexican banking have not always permitted it.

Commercial banks in Mexico have undergone major transformations in the past three decades. Expropriation in 1982 was followed by a process of privatization in 1994 and 1995. Then in 1998 most of the restrictions of foreign investment were lifted, and by the start of the 2000s the main banks were being bought by foreign financial institutions (Cárdenas, 2010).

It may be concluded that the thoroughgoing transformations in Mexican banking in the past three decades, which have led to changes in the business model and in the staff dealing with firms, seem to militate against close relations between the banking and production sectors and, therefore the credit supply to micro-enterprises and SMEs.

In addition to the findings of the questionnaire, Brown and Domínguez (2010) argue that the banking crisis of 1994-1995 laid bare the need for change in the way financial institutions operated, which led to the creation of new government schemes and instruments to facilitate access to credit for micro-enterprises and SMEs.

The first group of results produced by the present research work offers accurate and detailed information on the business strategy of commercial banks in Mexico as regards lending to micro-enterprises and SMEs. For example, 11 of the 15 banks interviewed have a line of business for micro-enterprises and SMEs and a specialized strategy for them. $73 \%$ of the institutions surveyed offer micro-enterprises and SMEs five or more different products, aiming to provide comprehensive solutions and reduce information asymmetries. There is a widespread practice of extending credit only to firms that can show at least two years of operations, which precludes loans to entrepreneurs. Lines of working capital are the most common loan product. ${ }^{17}$ There are major differences in the strategies followed by commercial banks in their dealings with micro-enterprises and SMEs, however, with

\footnotetext{
17 This product gives the client access at any time to a contingency loan up to a pre-authorized amount, to cover short-term needs.
} 
diverse business models and strategies. In this regard, banks may be grouped into three types: (i) large banks, (ii) niche banks devoted to promoting entrepreneurship and the production sector, or regional banks, and (iii) banks that do not have specialized micro-enterprise/ SME units.

This study's second contribution is to validate or refute eight factors that could hinder commercial bank lending to micro-enterprises and SMEs in Mexico, on the basis of the information provided by the banks themselves. Economic crises, especially the crisis of 1994-1995, have had a significant, long-term effect on the credit supply for small businesses. Macroeconomic variables are taken into account in setting total lending targets, and in lending to specific sectors or types of firm.

Because lending to micro-enterprises and SMEs is a large-scale business, transaction costs are a barrier for banks with smaller small business loan portfolios, but not for those with larger portfolios. Insufficient or poor quality information limits credit supply for microenterprises and SMEs. This barrier is greater in the case of informal firms and those whose operations are relatively new (less than two years old) and for entrepreneurs. For older, more formal or more professional firms, there are reliable sources of information, including credit bureaux.

The guarantee system in Mexico is not an obstacle for most of the banks interviewed, especially for those with larger portfolios and those with access to the government guarantee scheme. The difficulty and complexity of recovering collateral not backed by the government is a matter of concern, however.

The study found no evidence that the origin of capital, in particular the predominance of foreign-owned institutions in commercial banking, affects the credit supply to micro-enterprises and SMEs. None of the banks interviewed, regardless of where their capital came from, mentioned a differentiated strategy for dealing with small businesses.
The banks interviewed had a poor opinion of the creditor protection system. Slow processes, high costs and long, complicated recoveries represented a barrier to lending to micro-enterprises and SMEs. With respect to cultural factors, fiscal informality, lack of financial know-how and the "won't pay" culture form obstacles to lending to this business segment.

Lastly, the historical transformations in commercial banking in Mexico in recent decades, with changes in the business model and the staff dealing with firms at all levels, appear to work against close relations between commercial banks and the production sector.

The third contribution of this investigation has been to open avenues of future research. The implications of particular regulations — such as bank reserve requirements or the documentation firms must present to apply for a loan - need to be analysed for the different levels of business lending. In this regard, the impact of implementing Basel III must be studied.

The evidence and conclusions on the importance of certain factors could be strengthened by means of international comparison studies. For example, how do the average $2.8 \%$ transaction costs for banks in Mexico compare with those in other countries? And, although there is no evidence of a strategy differentiated by origin of capital, how do practices, loan amounts and lending approaches to micro-enterprises and SMEs differ from those in other countries where international banks operate?

Another area of interest is the effect of government lending schemes in terms of generating lending in addition to credit that would have been extended without them. In other words, although these guarantees have been important in reactivating business lending, at what point might they begin to substitute or crowd out commercial bank efforts?

A final avenue for future work is a detailed analysis of the differences and similarities found by supply- and demand-side surveys of commercial bank lending practices. 


\section{Bibliography}

Afuah, Allan (1999), La dinámica de la innovación organizacional, Mexico City, Oxford University Press.

Aghion, Phillipe and Patrick Bolton (1997), "A trickle-down theory of growth and development with debt overhang", Review of Economic Studies, vol. 64, No. 4, Oxford, Oxford University Press.

Arestis, Philip, Panicos Demetriades and Kul Luintel (2001), "Financial development and economic growth: the role of stock markets", Journal of Money, Credit and Banking, vol. 33, No. 1, Ohio, Ohio State University Press.

Audretsch, David B., Bonte Werner and Prashanth Mahagaonkar (2009), "Financial Signalling by Innovative Nascent Entrepreneurs", Discussion Paper, No. 7165, London, Centre for Economic Policy Research.

Ávalos, Marcos and Fausto Hernández (2006), "Competencia bancaria en México", Estudios y Perspectivas series, No. 62 (LC/MEX/L.722(Rev.2), Mexico City, ECLAC subregional headquarters in Mexico, June. United Nations publication, Sales No. S.06.II.G.155.

Banerjee, Abhijit and Andrew Newman (1993), "Occupational choice and the process of development", Journal of Political Economy, vol. 101, No. 2, Chicago, University of Chicago Press.

Barajas, Adolfo and Roberto Steiner (2002), "Credit Stagnation in Latin America", Working Paper, No. 02/53, Washington, D.C., International Monetary Fund.

Beck, Thorsten, Asli Demirgüç-Kunt and María Soledad Martínez (2010), "Foreign banks and small and medium enterprises: Are they really estranged?", Washington, D.C., World Bank.

Beck, Thorsten and Augusto de la Torre (2007), "The basic analytics of access to financial services", Financial Markets, Institutions and Instruments, vol. 16, Wiley.

Bencivenga, Valerie R. and Bruce D. Smith (1991), "Financial intermediation and endogenous growth", Review of Economic Studies, vol. 58, No. 2, Oxford, Oxford University Press.

Benhabib, Jess and Mark M. Spiegel (2000), "The role of financial development in growth and investment", Journal of Economic Growth, vol. 5, No. 4, New York, Springer.

Berger, Allen N. and Gregory F. Udell (2006), "Universal banking and the future of small business lending", Financial System Design: The Case for Universal Banking, Anthony Saunders and Ingo Walter (edit.), Burr Ridge, Illinois, Irwin.

Bittencourt, Manoel (2010), "Financial development and economic growth in Latin America: is Schumpeter right?", Working Papers, No. 191, Cape Town, Economic Research Southern Africa.

Blanco, Luisa (2010), "The finance-growth link in Latin America revisited and the role of institutions as a source of finance" [online] http//ssrn.can/abstract=1672839>.

Brown, Flor and Lilia Domínguez (2010), "Políticas e instituciones de apoyo a la pequeña y mediana empresa en México", Políticas de apoyo a las pymes en América Latina. Entre avances innovadores y desafios institucionales (LC/G.2421-P), C. Ferraro and G. Stumpo (comps.), Santiago, Chile, Economic Commission for Latin America and the Caribbean (ECLAC). United Nations publication, Sales No. S.09.II.G.143.

Caporale, Guglielmo Maria and others (2009), "Financial development and economic growth: evidence from ten new EU members", Discussion Papers of DIW Berlin, Berlin, German Institute for Economic Research.

Cárdenas Sánchez, Enrique (2010), "La reestructuración económica de 1982 a 1994", Historia crítica de las modernizaciones en México, Clara García Ayluardo, Ignacio Marván Laborde and Erika Pani (coords.), Mexico City, Fondo de Cultura Económica/ Centro de Investigación y Docencia Económicas.

Castañeda, Gonzalo and Clemente Ruiz (2006), "Los avances y los asuntos pendientes para la profundización de los servicios financieros en México", La extensión del crédito y los servicios financieros, Paulina Beato and Pablo Adrián (coord.), Madrid, Ibero-American General Secretariat.

Chandavarkar, Anand (1992), "Of finance and development: neglected and unsettled questions", World Development, vol. 20, No. 1, Amsterdam, Elsevier.

CNBV/BID (National Banking and Securities Commission/InterAmerican Development Bank) (2012), Encuesta Nacional de Competitividad, fuentes de financiamiento y uso de servicios financieros de las empresas. Reporte de resultados, Mexico City.

Cooley, Thomas F. and Bruce D. Smith (1998), "Financial markets, specialization, and learning by doing", Research in Economics, vol. 52, No. 4, Amsterdam, Elsevier.

De la Torre, Augusto, María Soledad Martínez Pería and Sergio Schmukler (2008), "Bank Involvement with SMEs: Beyond Relationship Lending", Policy Research Working Papers, No. 4649, Washington, D.C., World Bank.

FELABAN (Latin American Banking Federation) (2007), "Tracking sobre la predisposición de las entidades financieras de Latinoamérica y Caribe para la financiación de las pequeñas y medianas empresas", Caracas.

Fenton Ontañon, Rodrigo and Ramón Padilla-Pérez (2012), "Financiamiento de la banca comercial a micro, pequeñas y medianas empresas en México", Estudios y Perspectivas series, No. 135 (LC/MEX/L.1052), Santiago, Chile, Economic Commission for Latin America and the Caribbean (ECLAC).

Garmendia, Gonzalo (2006), "Acceso de las pequeñas y medianas empresas al financiamiento: Situación en América Latina y el Caribe", Ibero-American Guarantee Network, X Foro Iberoamericano de Sistemas de Garantía y Financiamiento para la Micro y Pyme, Castilla y León, Spain [online] http://www. redegarantias.com/index.php?not $=123$.

Garrido, Celso (2005), Desarrollo económico y procesos de financiamiento en México: Transformaciones contemporáneas y dilemas actuales, Mexico City, Siglo Veintiuno Editores.

Garrido, Celso and Francisco Prior (2006), Bancarización y microfinanzas. Sistemas financieros para las MIPYMES como un dilema central para el desarrollo económico de México, Mexico City, Editorial Porrúa.

Greenwood, Jeremy and Boyan Jovanovic (1990), "Financial development, growth and the distribution of income", Journal of Political Economy, vol. 98, No. 5, Chicago, The University of Chicago Press.

Greenwood, Jeremy and Bruce Smith (1997), "Financial markets in development and the development of financial markets", Journal of Economic Dynamics and Control, vol. 21, No. 1, Amsterdam, Elsevier.

Haber, Stephen (2005), "Mexico's experiments with bank privatization and liberalization, 1991-2003", Journal of Banking and Finance, vol. 29, No. 8-9, Amsterdam, Elsevier.

Habibullah, Muzafar Shah and Yoke-Kee Eng (2006), "Does financial development cause economic growth? A panel data dynamic analysis for the Asian developing countries", Journal of the Asia Pacific Economy, vol. 11, No. 4, Taylor \& Francis.

Lecuona, Valenzuela Ramón (2009), "El financiamiento a las pymes en México, 2000-2007: El papel de la banca del desarrollo", Financiamiento del Desarrollo series, No. 207 (LC/L.2997-P), Santiago, Chile, Economic Commission for Latin America and the Caribbean (ECLAC). United Nations publication, Sales No. S.09.II.G.04.

Leitao, Nuno (2010), "Financial development and economic growth: a panel data approach", Theoretical and Applied Economics, No. 10 (551), Bucharest, Asociatia Generala a Economistilor din Romania (AGER).

Levine, Ross (1997), "Financial development and economic growth: views and agenda", Journal of Economic Literature, vol. 35, No. 2, Nashville, Tennessee, American Economic Association. 
Lucas, Robert (1988), "On the mechanics of economic development", Journal of Monetary Economics, vol. 22, No. 1, Amsterdam, Elsevier.

Malhotra, Mohini and others (2006), Expanding Access to Finance: Good Practices and Policies for Micro, Small, and Medium Enterprises, Washington, D.C., World Bank.

McKinnon, Ronald I. (1973), Money and Capital in Economic Development, Washington, D.C., Brookings Institution.

Pavón, Lilianne (2010), "Financiamiento a las microempresas y las pymes en México (2000-2009)", Financiamiento del Desarrollo series, No. 226 (LC/L.3238-P), Santiago, Chile, Economic Commission for Latin America and the Caribbean (ECLAC). United Nations publication, Sales No. S.10.II.G.41.

Pino Hidalgo, Enrique (2002), "Financiamiento para la pequeña empresa: Una aproximación desde la sociedad civil", Comercio Exterior, vol. 52, No. 5, Mexico City, Bancomext.

Rajan, Raghuram G. and Luigi Zingales (1998), "Financial dependence and growth", American Economic Review, vol. 88, No. 3, Nashville, Tennessee, American Economic Association.
Saci, Karima, Gianluigi Giorgioni and Ken Holden (2009), "Does financial development affect growth?", Applied Economics, vol. 41, No. 13, Taylor \& Francis.

Sirri, Erik R. and Peter Tufano (1995), "The economics of pooling", The Global Financial System: A Functional Perspective, Dwight B. Crane and others (eds.), Boston, Harvard Business School Press.

Stiglitz, Joseph (1989), "Financial markets and development", Oxford Review of Economic Policy, vol. 5, No. 4, Oxford, Oxford University Press.

Stiglitz, Joseph and Andrew Weiss (1981), "Credit rationing in markets with imperfect information", American Economic Review, vol. 71, No. 3, Nashville, Tennessee, American Economic Association. Suárez Dávila, Francisco (2010), La reprivatización bancaria fracasada: Tragedia nacional en 3 actos, Mexico City, Centro de Estudios Espinosa Yglesias.

Tovilla, Carlos M. (2002), "Las garantías de crédito en México", Comercio Exterior, vol. 52, No. 7, Mexico City, BancomeXt.

World Bank (2007), Informality: Exit and Exclusion, Washington, D.C. 